\title{
The Liquidation of Art in Contemporary Art
}

\author{
Wolfram Bergande
}

\begin{abstract}
A B STRACT In this paper, the concept of liquidation (Verflüssigung) from the chapter on Self-consciousness in Hegel's Phenomenology of Spirit is reconstructed and then used to deconstruct the systematic transition from sculpture to painting in the passage on the "System of the individual arts" in G.W.F. Hegel's Aesthetics: Lectures on Fine Art. The aim is to show that such a deconstructed version of Hegel's art philosophy provides a valid conceptual framework for the analysis of modern, particularly postmodern and contemporary art, which results as liquid or liquidated art. Damien Hirst's For the Love of God is discussed as major evidence for the concomitant neo-Hegelian claim that modern art has discursive reflection as its necessary supplement. KEYWORDS Liquidation, deconstruction, subjectivity, G.W.F. Hegel, Gerhard Richter, Schädel [Skull] (1983), Damien Hirst, For the Love of God (2007)
\end{abstract}

Painting does not at all feel the lack of the third dimension; [...]

- Hegel, Aesthetics ${ }^{1}$

\section{Introduction}

Is discursive reflection a necessary supplement of modern art? In what follows I want to argue that: yes, it is essential to modern art, the term modern including post-modern and contemporary art. My argument will run along the lines of a deconstructive extrapolation of Hegel's aesthetics which by the same token will be defended as valid theoretical framework for the analysis and interpretation of contemporary art. Hegel's aesthetics will be defended despite the many metaphysical presuppositions of Hegel's concept-idealism which cannot be accepted today. The defense builds on a deconstructive reading of some passages from the section "The System of the individual arts"2 of Hegel's Aesthetics, a reading which will allow to extrapolate Hegel's liquidation of art and to project it onto the work of contemporary artists like Gerhard Richter or Damien Hirst.

The aim of this extrapolation is to substantiate three concomitant claims: firstly, that from a neo-Hegelian viewpoint there is contemporary art, and a substantial one, despite what Hegel called the Vergangenheitscharakter, the characteristic pastness of the modern artwork; secondly, that at least the works of modern art discussed below lend themselves to an interpretation in such an extrapolated neo-Hegelian framework; thirdly and conclusively, I want to make a case for the 'Romantic' character of modern artworks (to use Hegel's term), that is for the idea that they carry a reflexive surplus which is in need of discursive articulation. The discussion of the prime evidence in this case, Hirst's For 
the Love of God, at the end of this paper purports to show that discursive reflection is an essential trait of modern art. The gist of the argument is that critical reflection similar to the one developed in this paper is what makes the difference between a mere artifact sold on the art market and a work of art.

Like the liquidation of art, which Hegel's lectures on aesthetics (given in Berlin in the 1820 s right until his death in 1831) both announce and realize, and like the lectures as a whole, this extrapolation can only be understood against the background of Hegel's theory of subjectivity as primarily laid out in the Chapter on the dialectic of Lordship and Bondage in the Phenomenology of Spirit. Liquidation of art is an expression which is sometimes related to Adorno, who speaks of "art's liquidation"3 in his Aesthetic theory, or to Walter Benjamin's writings, notably his Einbahnstraße or his Das Kunstwerk im Zeitalter seiner technischen Reproduzierbarkeit, for example by Susan Buck-Morss. ${ }^{4}$ Yet the concept as well as the expression spring from Hegel's aesthetics and the theory of subjectivity which informs it.

The crucial entry point for the following deconstructive extrapolation will be the threshold where according to Hegel pastness befalls the arts, an incidence which comes about precisely at the passage from what Hegel calls Classical art to Romantic art, Classical and Romantic art being epitomized in ancient Greek art and Germanic-Christian art respectively. The importance of this passage for Hegel's aesthetics is sometimes underestimated. However, it actually marks a decisive transition as it coincides with the passage from the spatial three-dimensionality of sculpture to the two-dimensionality of painting (and on to the purely temporal one-dimensionality of music and poetry) - a passage which mirrors only in an outward fashion the decisive fact that in Romantic painting the divine absolute is no longer conceived of as something external to the spectator's subjectivity but has been realized as an integral part of it (or rather his subjectivity as an integral part of the absolute). In a wider perspective, this internalization of the absolute by modern subjectivity, which to Hegel is the absolute's self-realization in and through modern subjectivity, points to the structurally similar sublimation of an object-relation in Freudian psychoanalysis.

\section{Where Hegel Was (Almost Absolutely) Right and Where He Was Not}

One fundamental respect in which Hegel's meta-narrative can be defended is the following: Hegel saw that in terms of ontology the Selbstvergegenwärtigung (self-realization) of self-consciousness moves 
towards ever higher degrees of reality, from the expressly fictional representation in art to the passionate internalization of a firmly believed content in religion and on to conceptual thought which grasps the absolute substance/subject of reality in philosophical science. With respect to the arts, this movement explains phenomena like the current marketing driven aesthetization of the life-world, the performative turn of many art disciplines and the vanishing boundaries between the arts, the sciences and everyday life. ${ }^{5}$ It is subjectivity itself which is moving here, and Hegel's account of the aesthetic integrates into his account of the logical evolution of subjectivity. Hegel's theory of subjectivity is a narrative about the development of subjectivity, the ultimate Bildungsroman - and such is his aesthetics, which is a narrative about the evolution of basically religious worldviews and self-conceptions of subjectivity and how they express themselves in works of art.

Hegel was not quite right in at least two respects. First, there seems to be no ultimate narrative, in any case "[...] not [...] a single metanarrative for the future history of art". ${ }^{6}$ But that does not verify the postmodern verdict that the "grand Narratives" Rather, there are moral, political, aesthetic and logical reasons to prefer, time and again, one narrative over another (and there are in turn good reasons to unite these reasons in consistent metanarratives following each other).

Secondly, Hegel famously claimed that art, being bound to the sensuous realm, was no longer able to communicate the highly self-reflective subject matter of modernity - and that therefore it was a thing of the past. Hegel based his claim on his conviction that the modern, that is the Christian subject, has actually and fully sublated (aufgehoben) corporeality. Our bodily existence would be a necessary but passing moment of ourselves as spiritual beings. Today we oppose Hegel in this point. We hold that, despite Christianity's redemption, subjectivity remains passionately bound to its bodily existence and the concomitant needs and desires. As such, the sensuous is irredeemable. It is a passionately resisting rest, a Kantian Ding-an-sich. Its redemption, if there is one, is hence the infinite vocation of art, its theoretical reflection the infinite vocation of aesthetics.

Yet the main tendencies that Hegel diagnosed prevail, not only the tendency towards ever higher degrees of (self-)realization but also the vectors that drive art towards Verinnerlichung (internalization) and towards Vergeistigung (that is towards self-reflexivation as dematerialization). As a result, the modern arts have become poetic in Hegel's sense. This 
means that whatever medium they work on, they dwell in the universal medium of fantasy. It also means that they have various forms of conceptual reflexivity as a discursive surplus, a necessary supplement in Derrida's sense of the expression, for instance curatorial or art critical texts, commentaries in exhibition catalogues or conferences on aesthetics.

One major metaphysical presupposition of Hegel's philosophy is the following: what is, 'is' in the ontological sense of being the ultimate substance-subject, is a conceptual structure, a structure of which our worldly reality, including our bodily existence, would be an essential yet essentially passing moment. It is particularly this assumption which is the basis of Hegel's ill-received judgment on art as a thing of the past with respect to its highest vocation. Of course, today this assumption should no longer be defended. Reflection or reflexive thinking is a cognitive move in the central nervous system of speaking animals. It is not part of a spiritual super-structure which could, in an ontological sense, contain or sublate the speaking animal's death. However, once turned upside down and put from its idealist head on its feet, as Marx would have it, Hegel's aesthetics and the theory of subjectivity it implies can be made to allow for if not to account for the passionate remainder, the irredeemable rest, the - to speak with Sigmund Freud - unconscious core of modern subjectivity.

To do so, one has to turn to Hegel's paradigm of subjectivity, namely his conception of self-consciousness or Spirit (Geist). It is famously developed in the narrative about lord and bondsman in the Phenomenology of Spirit, in the Chapter on "Independence and Dependence of SelfConsciousness; Lordship and Bondage". ${ }^{9}$ For the sake of the following argument one remark concerning the title is indicated. In this title and elsewhere, particularly in the Aesthetics, the English terms "independence" and "dependence" are not really felicitous translations of the corresponding terms in the German original, which are Selbständigkeit and Unselbständigkeit. It is known that in Hegel's philosophy they refer to the concept of substance as developed by a long philosophical tradition that reaches from Aristotle to Descartes and Spinoza ${ }^{10}$ and on to Kant; and they also might be an implicit reference to the notion of Selbständigkeit in the writings of Johann Gottfried Herder. ${ }^{11}$ Now these terms correctly render, it is true, the notion of professional independence, which is the same in German where one would speak of selbständige as of liberal professions, for instance of medical doctors or lawyers which are selfemployed and work on their own account. But this modern notion is a mere connotation here. 
The translation by "dependence" and "independence" obfuscates the etymological import of the German noun Stand. Among other things, Stand can stand for: standing, having a standing, standing on one's own feet, being a stand-alone, standing something. Historically, it can also refer to belonging to a certain Stand, namely to one of the medieval estates of realm. So it connotes the idea of a certain social order. Both the German noun Stand and the English nouns estate and state refer back to the Latin noun status, meaning state, status, condition position, place, rank - which, by the way, in turn connotes property, patrimony, power, and capital funds. This translation and its underlying etymology are emphasized here not only because of the economic connotations which will become important in the following but also because the noun Selbständigkeit and the adjective selbständig are Leitmetaphern, guiding metaphors, of Hegel's Aesthetics.

The Phenomenology's rational mythology narrates how the perilous conflict between lord and bondsman stabilizes in a hierarchical power relationship before it resolves into a truly human one, a reciprocal relationship where these two forms of consciousness will have transformed into what Hegel calls self-consciousness. The eventual result, a synergetic relation of two or more self-consciousnesses which mutually recognize each other, is what in the Frankfurt School survived as the conceptual cornerstone of Critical Theory. Axel Honneth suggests that this Hegelian self-consciousness understood as bilateral or multilateral spirituality is the "rational universal". ${ }^{12}$ The "Hegelian idea of a rational universal"13 is the paradigm according to which inter-subjective relationships must be modeled and understood. It applies to all genuinely social or cultural phenomena that are products of subjective activity, notably to art. This neo-Hegelian or neo-Marxist paradigm would be valid even if the mutual recognition may fail or may show distortions, also if it must always be mediated - and if mediation requires a sensuous support, a support that eventually may resist complete idealization or dialectical Aufhebung (sublation). Of course, this is in sharp contrast to Hegel's belief that a complete absorption of sensuous substance in spiritual subjectivity is the necessary telos of the dialectical process. And it consequently opposes Hegel's claim that works of art, given that they are per definition worked out or performed in the sensuous realm, would be a thing of the past.

\section{The Art of Mastering Death}

A closer look at this famous narrative from the Phenomenology of Spirit will highlight a brief passage that marks the decisive turning point of the 
process which will lead to the mutual recognition of one self-consciousness by the other. Just before this turning point, the consciousness which has become bondsman has entered servitude. This is so because threatened with death it has given in. It is subdued by the other consciousness which has become its lord.

In this servitude, Hegel writes,

its whole being has been seized with dread; for it has experienced the fear of death, the absolute Lord. In that experience it has been quite unmanned, has trembled in every fibre of its being, and everything solid and stable has been shaken to its foundation. But this pure universal movement, the absolute melting-away of everything stable [das absolute Flüssigwerden alles Bestehens], is the simple, essential nature of self-consciousness, absolute negativity, pure being-for-self, which consequently is implicit in this consciousness. This moment of pure being-for-self is also explicit for the bondsman, for in the lord it exists for him as his object. ${ }^{14}$

The consciousness which has become bondsman has experienced the fear of death, of the absolute lord. It is reigned by fear and trembling. Everything stable, everything which has a Stand, a standing, melts away. Thus the subject which is bondsman becomes totally shapeable, mouldable. It melts into an inner, implicit "pure being-for-self". Here the English translation by Miller does render the etymological import of the Indo-German root stâ. The "absolute melting-away of everything stable" translates the German: das absolute Flüssigwerden alles Bestehens. The nominal expression "Bestehen" again refers to Stehen and Stand, that is to standing. More importantly, Flüssigwerden literally means becoming fluid. This may mean, as has been said: mouldability, formability, plasticity - not exclusively, but also in the artistic sense. ${ }^{15}$ Moreover, Flüssigwerden connotes mortality in the sense of liquidating somebody, of killing somebody. It furthermore connotes liquidation as financial operation, as the winding-up of a business or the settlement of capital assets, as sellout or closing sale.

During the enforced labor in the service of the lord that will follow, the bondsman will work out in an objective fashion this pure-being-forself which before he only implicitly was. Shaping nature and shaping its own nature, the bondsman enters a process of self-formation as he realizes and finalizes the implicit being-for-self in an objective form, giving explicit shape to his implicit mouldability. As a result, he gains an objective intuition of himself and hence becomes self-conscious. "Through his service he [the bondsman] rids himself of his attachment to natural 
existence in every single detail; and gets rid of it by working on it."16 In pre-modern times, at any rate, this is a predominantly sensuous, hence aesthetic work process. And Hegel's lectures on aesthetics accordingly tell the story of the history of world art as a story of how to deal with and overcome death by shaping sensuous material.

From the view of Critical Theory, for example Adorno's, it is precisely here that modern subjectivity and Hegel have failed. The modern subject cannot fully mould its pure being-for-itself into a sensuous object, thereby liberating itself as self-consciousness. Rather, it keeps on being subjected, and its own body is the point where the dialectical liquidation is stuck. Modern subjectivity is split or broken due to an unconscious, natural rest. It is a rest which shows - not only in Hegel's transition from sculpture to painting, but also there. In the epigraph of this paper Hegel is quoted insisting that "[p]ainting does not at all feel the lack of the third dimension; [...]", and he continues by asserting that far from feeling the lack "[...] it discards it deliberately in order to substitute for what is simply a real object in space the higher and richer principle of colour". ${ }^{17}$ By contrast and much later, Adorno will warn that "[... no picture, not even an abstract painting, is completely emancipated from the world of objects"18 and that therefore "[...] even the most spiritualized painting is heavily burdened with unresolved objectivity". ${ }^{19}$

Hegel would have disagreed. And as he emphasizes in the last sentence of the paragraph quoted above, the pure being-for-self is not just implicit in the bondsman. The lord already represents for him this pure being-for-self in an objective fashion. This is in accord with Hegel's idea of art history. Art-historically speaking, for Hegel the subject matter of the arts has been for the longest time the divine being as absolute power, a power whose divinity is proved precisely by the fact that in one way or the other it masters even death. Examples would be the Egyptian Sphinx, Buddha, Zeus and Jesus. So the ultimate subject matter of (any) art for Hegel is the overcoming of death by the divine - precisely, by a divine spirit that for us moderns turns out to be intersubjective human selfconsciousness, a certainly mortal form of spirit in the sense of Honneth's rational universal. As essential as the sublation of the sensuous through its mortification is to Hegel's philosophy of art, it nevertheless eludes some of Hegel's most recent commentators. ${ }^{20}$

For Hegel, the advent of Christianity and the historical person of Jesus Christ is the crucial turning point in art history. For the spirit of Christianity, the sensuous matter as such must be liquidated, sacrificed, in order to show that self-consciousness as spirit is independent of it, that it is 
truly selbständig, stand-alone. As was mentioned at the beginning, it is to show that the bodily existence is only a passing moment in an essentially spiritual structure. This moment is concentrated in the passion of the sensuous body of Christ. Through the crucifixion of the divine Christ, the marble of the Greek gods gets mortified and eventually sublated, like any "[s]ensible nature, immediate singularity" it "is nailed to the cross", as it is succinctly put in Heinrich G. Hotho's transcript of Hegel's 1824 Lectures on the Philosophy of Religion. ${ }^{21}$ Art, which is necessarily tied to a sensuous object, becomes absolutely fluidized. And this means that art becomes more-than-fluid, superfluous, expendable, it literally disappears. It is, as Hegel notoriously claims, a thing of the past, nota bene if and only if considered in its highest vocation, namely the vocation to bring, through sensuous objects, to the mind of the subject what the subject essentially is.

\section{Apparent Superfluity or Superfluous Appearance?}

It is quite noteworthy that at a later point in the Aesthetics Hegel appears to relativize the radicalness of his notorious claim. In the chapter on the Romantic art form, he seems to no longer insist on the pastness of art. Instead he talks about what the compiler and editor Hotho labels a merely "Apparent Superfluity of Art". ${ }^{22}$ Only apparently, not strictly speaking, would art be superfluous or expendable. Why? If art appears to be superfluous, it is, Hegel tells us, because Christianity has come to inform subjectivity. Now that the mere consciousness of truth, the inner conviction suffices, "beauty of appearance"23 and sensuous "representation"24 are no longer necessary for subjectivity to grasp what it truly is. So what remains from the capital task of art and aesthetics, namely the task to realize subjectivity via the presentation of and reflection upon a sensuous Schein (appearance), is the presentation of the disappearance of spirit, of its vanishing out of the realm of sensuous representation. So only apparently would art be a thing of the past. What must keep on appearing or rather dis-appearing is precisely its pastness.

As a matter of fact, one may wonder whether at this point Hegel is true to himself. In a strict interpretation of Hegel's philosophy of art, it could actually seem more legitimate to argue that art is a superfluous appearance rather than a merely apparent superfluity. For if spirit can only be adequately brought to mind, i.e. reflect upon and realize itself, in more dematerialized and internalized forms of spiritual life, namely in religion and ultimately in philosophical science, why should art continue to mark its own limits? Why should it so to speak bump its head against an 
invisible wall again and again? All that spirit would be able to take out of that would be that here, in the realm of art, it seeks in vain for adequate self-realization. According to Hotho's rendering of Hegel, however, this is what the Schein, the pure appearance of art, does. It does not become superfluous in a straightforward manner, it does not disappear sensu strictu. Rather and more precisely it keeps on disappearing, infinitely. It is a disappearance that infinitely shows.

Most notably it shows in the transition from the middle to the third stage of world art in Hegel's aesthetics, from the so-called Classical art form to the so called Romantic art form. As has been mentioned in the introduction, this transition corresponds to another transition, a transition within Hegel's hierarchy of the art disciplines, namely the transition from the three-dimensional plasticity of sculptural works to the twodimensional ideality of painting. With painting, the third dimension of three dimensional space, its objective plasticity, which is an essential part of the Selbständigkeit of sculpture, gets sublated, idealized, and thus it gets internalized as something that, in its highest vocation, is merely for-the-subject, a pure being-for-self. At the same time, in this very process, the divine being, Spirit, passes over, according to Hegel, from the selbständige sculptural work into the Gemeine, into the united consciousness of the individuals of a spiritual community. It ceases to be outside of self-consciousness. Instead, self-consciousness now and for the first time recognizes it as a moment of its own essence. Hegel:

[...] [T] he object which it [painting] presents does not remain an actual total spatial natural existent but becomes a reflection of the spirit in which the spirit only reveals its spiritual quality by cancelling the real existent and transforming it into a pure appearance in the domain of spirit for apprehension by spirit. $^{25}$

Whereas sculpture is selbständig, stand-alone, and apparently indifferent to the spectator, painting, by contrast, "acquires a far closer relation to the spectator", ${ }^{26}$ given that it

[...] contracts the spatial totality of three dimensions. Their complete contraction would be their concentration into a point which implies cancelling all juxtaposition and, in this cancellation, a restlessness like that belonging to a point of time. But only music goes to the length of carrying out this negation completely, and logically. ${ }^{27}$

Now that Selbständigkeit has passed from the sculptural artwork into the self-consciousness of the spectator, the former relation between the selb- 
ständige sculptural artwork and the spectator becomes internalized and emerges as an internal relation of the subject to itself (precisely insofar as this relation is mediated by the painting). But this difference, which emerges as a "separation", ${ }^{28}$ and which no doubt is (in an ontologically substantial sense), is not supposed to show itself. This is of capital importance. According to Hegel, it is a priori taken back, absolutely retained in or rather as the pure appearance of the idealized third dimension of painting - with the result that the virtual space of painting, the third dimension, is appearance and disappearance at the same time, a form of "pure appearance"29 which appears as an absolutely dematerialized, spiritual medium. What follows is a longer quotation from the section on "The Sensuous Material of Painting"30 of Hegel's Aesthetics to make this point clear:

The statue is predominantly independent on its own account, unconcerned about the spectator who can place himself wherever he likes: where he stands, how he moves, how he walks round it, all this is a matter of indifference to this work of art. If this independence [Selbständigkeit] is to be preserved, the statue must give something to the spectator wherever he stands. But this independence [Selbständigkeit] the work of sculpture has to retain because its content is what is, within and without, self-reposing, self-complete, and objective.

Whereas in painting the content is subjectivity, more precisely the inner life inwardly particularized, and for this very reason the separation in the work of art between its subject and the spectator must emerge and yet must immediately be dissipated because, by displaying what is subjective, the work, in its whole mode of presentation, reveals its purpose as existing not independently on its own account but for subjective apprehension, for the spectator.

The spectator is as it were in it from the beginning, is counted in with it, and the work exists only for this fixed point, i.e. for the individual apprehending it. Yet for this relation to vision and its spiritual reflection the pure appearance of reality is enough, and the actual totality of spatial dimensions is really disturbing because in that case the objects perceived retain an existence of their own and do not simply appear as configurated artificially by spirit for its own contemplation. ${ }^{31}$

The statue gives something to the spectator wherever he stands, it is selbständig and apparently indifferent to the spectator and his own Selbständigkeit. Of course, as the sculpture like any work of art is mediated through and through, in its case, too, the spectator will always have been presupposed, if only implicitly. Yet at one point of the trajectory the implicit being-counted-in of the spectator as such will become apparent to the spectator. This is what happens in painting, namely through the 
idealization of the third dimension of space - says Hegel. For us moderns, this idealization is never absolute. A famous painting by Hans Holbein the Younger, Die Gesandten / The Ambassadors, can serve as a backup for this claim:

With the anamorphic skull in the foreground of The Ambassadors, an icon of death, the spectator experiences something that, contrary to Hegel, is "configurated artificially" in the above sense and yet does retain an existence of its own. By virtue of being an anamorphosis, it is artificially contrived. Yet at the same time it is not dissipated, as Hegel would have it. It stands out from the idealized two-dimensionality of the painting. It is precisely not submerged in the pure appearance of the idealized third dimension of painting. Quite similar to a sculpture, the anamorphic painting gives to the spectator more than one point of view. It defies and disintegrates the concentrating cancellation of the third spatial dimension, its sublation (Aufhebung) into the spectator's single point of view.

For the post-Freudian psychoanalyst Jacques Lacan, who took up this example from Salvador Dalí when they became acquainted in the early 1930s, the anamorphosis in Holbein's ambassadors instantiates the distorting disappearance of the imaginary subject, its vanishing into the unconscious. In his Seminar XI The Four Fundamental Concepts of Psychoanalysis, Lacan calls this moment the fading of the subject. The anamorphic skull, a symbol of vanitas and memento mori, instantiates a strictly irredeemable perspective, the standpoint of the subject of the unconscious which continues to haunt the spectator's Selbständigkeit, that is: the spectator's ego-identification with the visually represented shape of his or her erected body.

Against the background of Lacan's interpretation we can say, with respect to Hegel and in terms of his aesthetics, that the anamorphosis shows the resisting Selbständigkeit of the sensuous medium, an existence which appears to be of its own, and which haunts our own Selbständigkeit as spectators, as spectators who are embodied, mortal subjects. This puts a restriction on our 'freedom of consideration' which Hegel had assumed to be higher in painting than in sculpture. Holbein's anamorphosis is a kind of plasticity that does not conform to the imaginary space of the idealized, sublated third dimension in painting. It makes the radical, unaccountable disappearance of something spiritual appear, of something sensuously invisible. Self-consciousness turns inward, but there is something, some appearing resistance or negativity, which, as is argued here, remains the placeholder of the passionate attachment to bodily existence. In this vein, Derrida ${ }^{32}$ and Lacan had kept on repeating against 
Hegel that there is something that cannot be sublated into what Hegel calls Spirit. Art and aesthetics are supposed to come to an end; yet they will never stop working out this rest which art cannot fully integrate and which aesthetics cannot fully account for.

With regard to Hegel, the crucial and indeed tricky question here is whether Holbein's anamorphosis represents a case of appearing superfluity that is accounted for by his aesthetics or whether it does not. Both answers seem possible: that it be an appearing superfluity - or instead just a superfluous appearance. For on the one hand, being a special kind of virtual depth in painting, it really does not seem to fit into Hegel's account of the passage from sculpture to painting as reconstructed above. Also, from the standpoint of art as a thing of the past, one could say that the anamorphic skull is a genuinely superfluous appearance and that Holbein would better have done without it. Given that it emphasizes mortality, it marks a step in the development of selfconsciousness which for a long time has been overcome by Christianity's promise of eternal life.

Yet on the other hand the melted ideality of the anamorphic skull could be taken to be precisely the apparent or rather appearing superfluity of art which according to Hegel remains necessary. For in the context of the apparent superfluity of art which is about to be displaced by religion Hegel asserts that despite this superfluity, "[...] the religious material contains in itself at the same time a factor whereby it is not only made accessible to art but does in a certain respect actually need art" (Hegel 2010a: 535). So maybe Holbein's anamorphosis is precisely an actualization of this somewhat obscure "factor" and the need for art it necessitates - particularly since it "involves pushing anthropomorphism to an extreme" ?33 If both answers could be defended on the basis of the text of the Lectures, then it seems that here Hegel's text is somehow twisted.

\section{Liquid Capital Display Or "This Is Not a Skull"}

This twist or ambivalence in the text of the Aesthetics can be pushed further by looking at the passages which follow the quotation just given. There, Hegel diagnoses a clear tendency within the romantic arts - painting, music and poetry - towards a Verselbständigung, a becoming-independent, of pure form. By the way, these are the passages in which Hegel's aesthetics is most contemporary to our time and in which he anticipates modern abstraction and symbolism in the arts. According to Hegel it is particularly painting which lends itself to such a spin-off towards pure form. Much more than the Symbolic or Classical arts, architecture and 
sculpture, it admits a certain falling apart of form and content. In the section on the "Principle of the Artistic Treatment", Hegel states:

More than architecture and sculpture, painting admits of two extremes: what is made the chief thing is (a) the depth of the subject-matter, i.e. religious and moral seriousness in the treatment and presentation of the ideal beauty of form, and (b), in the case of insignificant subjects chosen by the artist, the details of them as they actually are and the subjective skill of the artist in his work. ${ }^{34}$

$[\ldots][\mathrm{P}]$ ainting must press on to the extreme of pure appearance, i.e. to the point where the content does not matter and where the chief interest is the artistic creation of that appearance. ${ }^{35}$

If painting does so, if it enters this path of abstraction and pure make, then it creates a magic moment. Here is an example for such a magic moment. It is a painting by Gerhard Richter of 1983. Like Holbein's The Ambassadors, it can be taken to refer to the traditional iconography which sees the skull as an icon of sensuous vanity and of a memento mori.

Richter's blurred photorealism evidently achieves advanced stages of Hegel's "pure appearance", of what he calls, in the section on the "More detailed Characterization of the Sensuous Material of Painting", ${ }^{37}$ its "objectless play" and its "magic":

This magic of the pure appearance of colour has in the main only appeared when the substance and spirit of objects has evaporated and what now enters is spirit in the treatment and handling of colour. In general, it may be said that the magic consists in so handling all the colours that what is produced is an inherently objectless play of pure appearance which forms the extreme soaring pinnacle of colouring, a fusion of colours, a shining of reflexions upon one another which become so fine, so fleeting, so expressive of the soul that they begin to pass over into the sphere of music. ${ }^{38}$

Against this background, Richter's Schädel, which at first may look like an outright overpainting of a photograph, seems to hint to the virtual third dimension of the unconscious subject precisely by flattening out this dimension - a phenomenon apparently similar to what Arnold Gehlen describes as "Verflächung" (flattening) of the pictorial space. ${ }^{39}$ Richter counters the pure appearance of photorealism, with its virtually flat depth and its tendency to nurture the illusion of a bare factuality objectively represented, by blurring it with a layer of oil paint - as if he wanted to deconstruct it by sealing it. Thus objectivism and subjectivism appear coagulated in the very moment in which, in an effect of "Zweischichtigkeit", ${ }^{40}$ two-layeredness, their critical distance towards each other is exposed. 

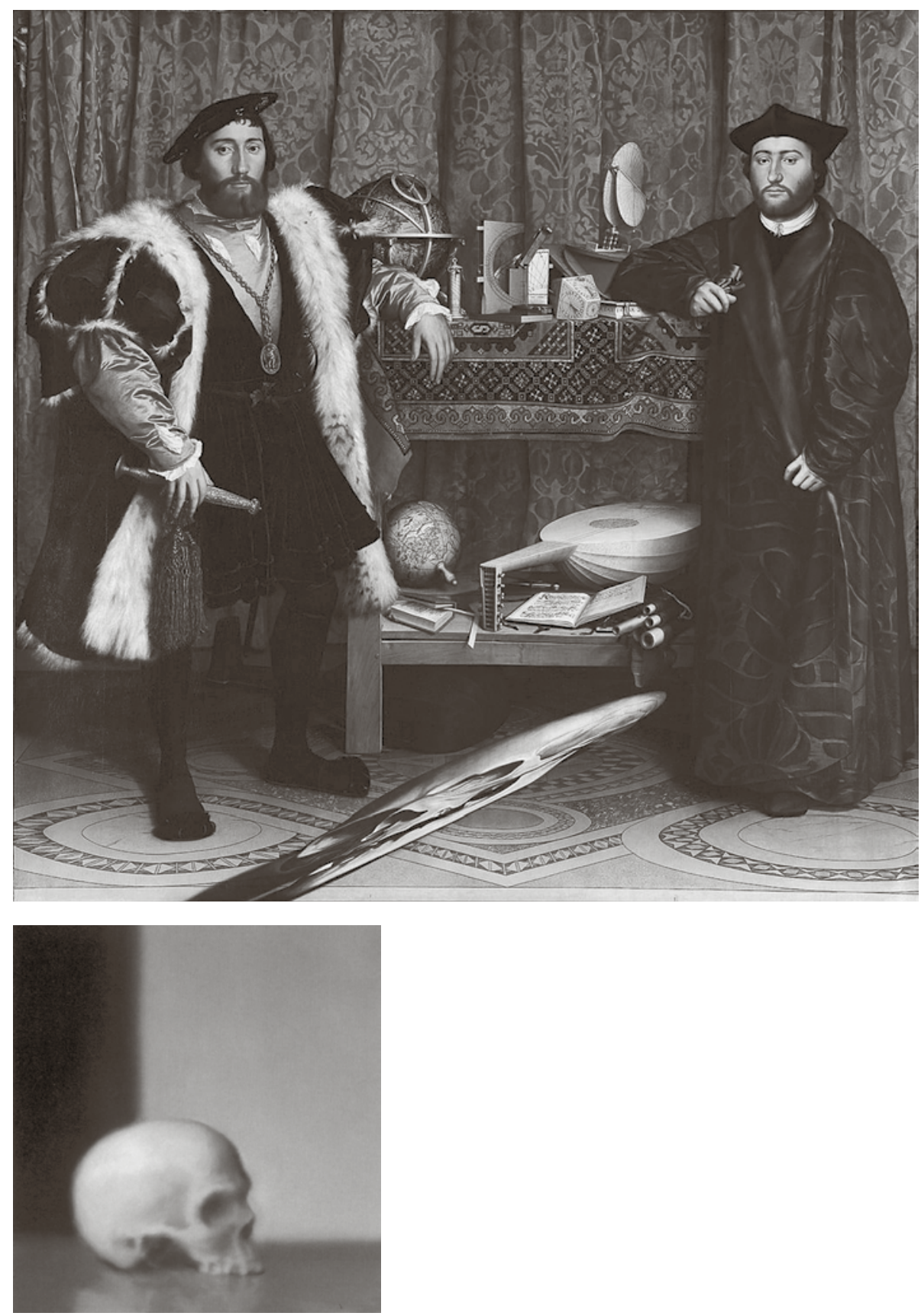

Gerhard Richter, Schädel ${ }^{36}$ [Skull], 1983. Oil on canvas. $55 \times 50 \mathrm{~cm}$.
Hans Holbein the Younger, Die Gesandten [The Ambassadors], 1533. Oil on oak. $206 \times 209 \mathrm{~cm}$. 
In some of his photographic works, e.g. 99 cent, the German visual artist Andreas Gursky achieves a similar exposure, by opposite means though: Gursky forces, as it were, the two layers together by pushing the photographic depth of field into an extreme extension and a homogeneous acuity. ${ }^{41}$

Gursky's somewhat forced depth of field hints to the fact that the magic of pure appearance worked out by contemporary masters like Richter is haunted by its reverse side. This reverse side, however, is not the concentration on the depth of the depicted content (Gehalt), as Hegel would have it. Rather, just as some of Gursky's photographs suggest, Hegel's Verselbständigung of form - which will develop in music even more - is haunted by a concomitant Verselbständigung of the sensuous medium. It is the brute, bare materiality of the sensuous medium which appears as the reverse side of the magic. It forms part of the absolute content of subjectivity - despite the subject itself which tends to identify with these magic forms of pure appearance.

In the view of the author of this paper it is today undoubtedly Damien Hirst's platinum-and-diamond skull titled For the Love of God of 2007 which illustrates best this reverse aspect of Hegel's Romantic arts. The artifact consists of a life-size platinum skull carrying a mosaic of 8,601 diamonds worth about $€_{1} 8$ million and sold for about $€_{75}$ million to an investor consortium to which Hirst himself belonged. ${ }^{42}$

So from a Hegelian point of view, one might tend to be rather brief here: Hirst's For the Love of God fetishizes to a maximum degree the third spatial dimension which, according to Hegel, is the crucial step from classical to romantic art, from sculpture to painting. And one could consequently claim that Hirst's plastic artifact must actually be interpreted not as what it appears to be, as a sculptural work, but as a strange kind of painting, as an intentionally regressive, i.e. perverse form of painting. Similar to the famous painting of a pipe by René Magritte The Treachery of Images [La trahison des images] (1929) which contains the phrase: "This is not a pipe [Ceci n'est pas une pipe]", Hirst's sculpture could hence be labeled with a similar phrase, e.g. with: "This is not a skull".

Whereas Richter took the road to the one extreme Hegel indicated, the one towards mere form, flattening out what Holbein had carved out anamorphically or what we find melted down in the cast glass of Sherry Levine's Pink Skulls of 2011, Hirst's diamond 'skull-pture' shows off the material side of the liquidity or superfluity of art. It presents a sensuous yet mortal matter which is totally exchangeable, totally liquid in an economic sense, a true master value encompassing any other value. As 

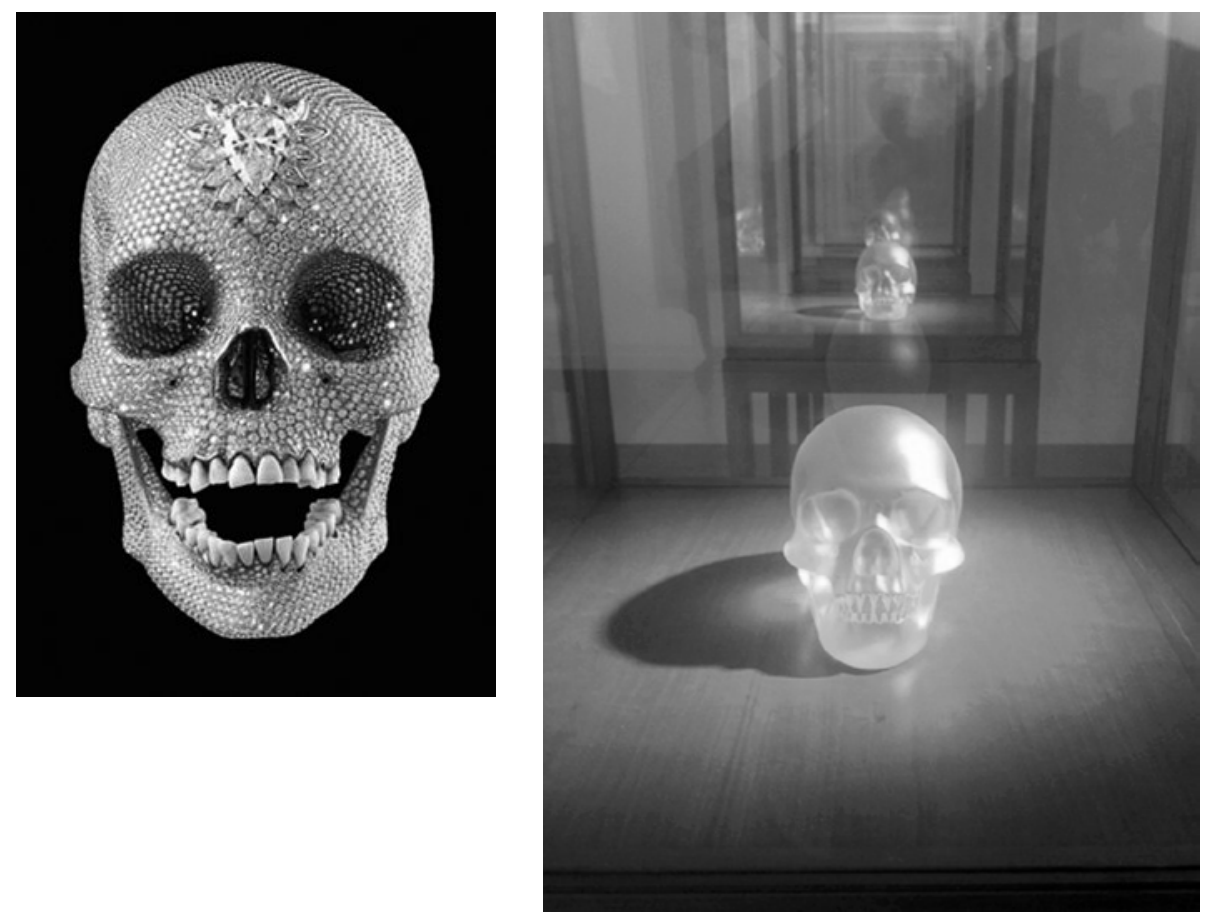

Damien Hirst, For the Love of God, 2007. Platinum, diamonds and human teeth. $17,1 \times 12,7 \times 19,1 \mathrm{~cm}$.
Sherrie Levine, Pink Skull (Edition of 12), ${ }^{43} 2011$.

Cast glass. $14 \times 17,8 \times 11,4 \mathrm{~cm}$. 
such it embodies the epitome of modern capitalist subjectivity. Yet in another sense, as caput mortuum, it is brute matter which can never become subject-matter in a spiritual sense. If Spirit was not a bone for Hegel, it is one for Hirst, who pushes Hegel's apparent superfluity of art towards a perverted maximum of absolute liquidation.

\section{Hirst Sells... but Who Is Buying?}

But then again the crucial question is whether this is actually done with Hegel or against Hegel. Does the totally capitalized subject-matter which Hirst presents to us subvert Hegel's concept of romantic art or is it its (negative) consummation? And would not to subvert it mean to refute it together with the primary, neo-Hegelian claim made in this paper that art essentially needs a supplementary discursive reflection? My answer is that Hirst does not at all subvert Hegel's liquidation of art, what he does is perverting it. This perversion already seems to show in Hirst's treatment of what was paramount to Hegel's idea of painting, namely "carnation". 44

Generally speaking and in the context of Hegel's aesthetics, carnation, as an art-theoretical concept, designates the absolute fusion of subject and matter in the sensuous realm of art. Beyond this realm, it refers, of course, to incarnation as the sensuous embodiment of the divine in Christian religion. More particularly and with respect to painting, it labels the expression of the vivacity of spirit in the flesh tints of the depicted sensuous body. Talking about carnation, Hegel gives preference to oil colors. Accordingly he explicitly disqualifies mosaics of differently coloured glass studs or stones. This applies perfectly to Hirst's artifact which is monochrome, tessellate, and plastic.

As for the material to be used for producing this lustreless vitality of flesh, the short answer is that oils alone have proved perfectly suitable for this purpose. Treatment in mosaic is least of all fitted for producing this effect of fusion of colours; its permanence is a recommendation but it has to express shades of colour by juxtaposing differently coloured glass studs or small stones and therefore it can never produce the flowing fusion of the ideal shining of one colour through another. ${ }^{45}$

Still one could reasonably argue that Hirst's perversion simply draws the however dire conclusions from Hegel's concept of Romantic art. For the Love of God would be absolutely liquefied, absolutely capitalized, like subjectivity in contemporary capitalist societies in fact tends to be. Therefore it would be absolutely Romantic in Hegel's sense, in any case 
as Romantic or modern as it could possibly get. ${ }^{46}$ If art is the sensuous object that presents this liquidity of capital, which is the liquidation of the caput, the "head" and "life" in Latin, then in Hirst's sculpture the artwork is reduced, as it were, to an LCD, a liquid capital display - a metaphor borrowed here from Esther Leslie. ${ }^{47}$ Yet seen this way, Hirst's work could also be regarded not as Romantic in Hegel's sense but rather Classical. For if this work is a regression, as it were, from painting to sculpture, then it might regain a function which artworks had according to Hegel on the level of the Classical art form, namely to give a sensuous representation of the abstract necessity which governs subjectivity. In the Lectures on the Philosophy of Religion compiled by Hotho, Hegel gives a corresponding art-historical example: the statue of Zeus by Phidias. Being the sculptural representation of a God, of the God-Father of the Olympian family, it is a prime example for what Hegel calls Classical art. For the ancient Greeks, explains Hegel, Phidias' statue of Zeus represented or rather veiled the abstract necessity, the ananke which the Greeks could not come to terms with, neither through art, nor religion, nor philosophy. All they were able to do was to acknowledge this abstract, blind and absolute power to which even Zeus had to bow. ${ }^{48}$

Today, in the era of reflexive modernity, when "[a]ll fixed, fast frozen relations [...] are swept away" and "[a]ll that is solid melts into air", ${ }^{49}$ this abstract power is, according to Marx' and Engels' German Ideology, the world market, namely the universal medium which constitutes and drives subjectivity as a commodified, totally capitalized and absolutely exchangeable value, as Marx claims in his Outlines of the Critique of Political Economy. In this vein, Adorno writes that

Bourgeois society is universally situated under the law of exchange, of the like-for-like of accounts that match and that leave no remainder. In its very essence exchange is something timeless; like ratio itself, like the operations of mathematics according to their pure form, they remove the aspect of time. [...] But this means nothing less than that recollection, time, memory is being liquidated by advancing bourgeois society itself, as a kind of irrational residue $[\ldots] .^{50}$

Facing the virtually universal power of today's world market, there are contemporary masters like Richter who stage the magic of the pure (dis-) appearance of art and thus allow for critical reflection. Hirst, by contrast, cashes reflection, precisely in the moment when he cashes in on his own artifact as a member of the consortium which bought it at the fivefold value of raw material. ${ }^{51}$ Like dark matter frosted with perverse 
glossiness, his diamond skull is a perfect example of what Adorno called the aesthetic "physiognomy of the culture industry": "[...] a mixture of streamlining, photographic hardness and precision on the one hand, and individualistic residues, sentimentality and an already rationally disposed and adapted romanticism on the other [...] decaying aura as a foggy mist". ${ }^{52}$

And like dark matter does, it absorbs almost any Schein (appearance) that could trigger a critical reflection. Executing the laws of postmodern capitalism, what Hirst indeed ventures is to liquidate the ultima ratio of subjectivity and its 'recollection, time, memory': the memento mori. That the spectator should know that Hirst bought his own product, and at great profit, is no doubt an essential element of the meaning of For the Love of God. As will be explained in the following section, this knowledge, being more than superfluous, entangles the spectator in a tacit complicity which is essential for the imaginary effects of aesthetic perversion.

\section{Du(m)ped by Hirst \& Co.}

All this strongly suggests that Hirst's skull has not just "money"53 as its subject, even though it may be interpreted as an "icon of capitalism". ${ }^{4}$ Also, in this view there is nothing sublime about it, as has recently been suggested by Luke White. ${ }^{55}$ Neither does it inspire a feeling of sublimity in the Kantian sense nor in the Burkian let alone Hegelian and not even the Jamesonian sense of a "postmodern sublime" ${ }^{\prime 56}$ which would hint at the "impossible totality" of "the whole world system of a present-day multinational capitalism". ${ }^{58}$ White argues that Hirst's skull "[... revolves precisely around the gap between the intellectual and the material, sensuous thing", ${ }^{59}$ yet that it could "only disavow"60 ideologically the "irreducible ambivalence" stemming from the "social antagonisms" haunting it. The skull would feed both the "more rational and 'positive' pleasures of mastery"62 and a certain "masochistic element", ${ }^{63}$ a possibly "narcissistic, oceanic investment in the death drive"; ${ }^{64}$ it would "exacerbate such a deathly narcissism of capital and commodity desire" as it "stops short before raising such a mechanism to consciousness and critique". ${ }^{65}$ White's text very well recognizes what is at stake in Hirst's case and his arguments are close to what is argued here. However his text does "not go enough distance to understanding how such works do function" ${ }^{\prime \prime 6}$ either and calls for some further explanation.

For strictly speaking Hirst does not at all revolve around or play with the gap between the intellectual and the material. Rather he straight- 
forwardly exploits this gap, seemingly with a brute material purpose. It is his preemptive act of buying (into) his own artifact which is at the root of this exploitation. Hence and sadly there is no "form of visibility $^{107}$ (White), if such a form is meant to imply whatever kind of reflexivity, reflexivity (not to mention critical distance) remaining the defining value of contemporary art in contradistinction to fetishistic kitsch. To indict for fetishism Hirst's after-modern showing-off may be old (Frankfurt) school. But it is fair enough. If there is disavowal of ambivalence in Hirst's case, it is precisely in the psychoanalytic sense of the winking disavowal of the perverse who necessarily exploits the complicity tacitly foisted on the beholder. And so it is anything but accidental that the perverted subject should stop short of achieving critical insights.

How does this perverse disavowal function? As it has been formulated by Octave Mannoni and further explored by Robert Pfaller, one decisive move is to install in the spectator some alleged 'better knowledge', knowledge (in inverted commas) which however only serves to pervert him by preempting and dumping his critical subjectivity and the moral standards it preserves. ${ }^{68}$ In Hirst's case, this is the eventually selfdeceiving 'knowledge' of somebody thinking by himself: "I know that the concentration of wealth in this artifact is obscene and malicious, I even know that when Hirst buys (into) his own product, the exploitation of my moral indignation might also be part of the preemptive game, etc. - however I feel attracted to the piece..." This position of alleged better knowledge gives the spectator the comforting illusion of staying out of the dumping game whereas it is exactly what eventually lures him into it. Which game? The enjoyment of the unmediated, materialized concurrence of pleasure and pain, of love and hate, or as White had already remarked: of the love and the death drive.

Dumping is here an expression for the pervert's double-faced game in which the subject undersells (dumps) its moral standards while at the same time and self-contradictorily reaffirming them, however only to be able to undersell them. This is one of two moments of the game. There is a second moment, involving another dumping, which is discussed below. In Hirst's case, the 'better knowledge' cunningly plays to our moral standards as it invites us to feel scandalized about the sale's exorbitant price and about the fact that Hirst bought the piece from himself. If we, the spectators, accept this (imperceptibly forced) invitation, then the position of 'better knowledge' spelled out in the paragraph above becomes foisted on us. Through the moral disgust which we accept to have incited in us our moral standards appear to 
be reaffirmed, yet only tokenistically, since by the same token they become objects of perverse speculation: Do we really mean them, in all their sublimity? Or are we ready to, so to speak, accept a mortgage (literally: a dead pledge) on Hirst's fascinating skull and undersell them if we're promised a high enough gain? Which gain would that be? And haven't we actually already sold them and accepted Hirst \& Co.'s mortgage, given that we form part of the globalized economy from which the capital funds to pay for it were taken? This leads to the second moment, the other dumping involved. The gain we are offered is to dump on the skull the residual and self-directed aggressivity accumulated by our own libidinal economy, in psychoanalytic terms: the unbound residues of the death drive resulting from the structural decomposition of the love drive and death drive. This is the other moment of Hirst's offer-you-simply-cannot-refuse. The two moments are two dialectical aspects of one and the same perverted subject-object relationship: we despise the artifact from our moral point of view (moment one) yet at the same time we love it because it binds and seems to redeem us from our residual aggressivity (moment two). But there is no catharsis or sublimation involved here, we really do not get rid of the slag of negativity. Supported by an alleged better knowledge, it has only become bound in a sensuous object to which we remain passionately bound because our contradictory passions are not mediated or sublimated.

As is known, in psychoanalysis it is the fetishized object which functions as the sensuous compound of despisement and love which makes this self-contradictory object-relationship not only livable but also enjoyable. The post-modern "ambivalence" ${ }^{\prime 69}$ enjoyed in this relationship is perverse in the psychoanalytic sense of the term, for pleasure and pain are thrillingly compounded (and here lies what White diagnosed as masochism). The conscience-stricken and therefore painful pleasure of transgressing one's standards compounds the concomitant pleasurable pain caused by the (albeit self-loathing) relief from one's conscience, and vice versa. The two feelings do not neutralize each other, let alone mediate or sublate one or the other as for instance in Kant's theory of the sublime where the sublime feeling is a "[...] pleasure [...] which is only possible through the medium of a pain" ${ }^{70}$

The thrilled fascination for fetishistic compounds like Hirst's skull is no doubt symptomatic for post-modernity. However one may ask why post-modernity's consumerist disavowal should not be a legitimate way of dealing with the "deathly enjoyment"71 originally repressed in modern subjectivity? And is it not after all a manageable way out of the un- 
finishable project of modernity? The answer is no, because in this way the fact that there is an irreducible and pleasurably painful destructivity at the heart of capitalist subjectivity remains unrealized. Even if this was a lesser problem in the morals department as it probably is, i.e. less problematic for example than modernity's so to speak neurotic way of repressing-sublimating the object, it is an epistemic one: For on the one hand the alleged 'better knowledge' about Hirst \& Co.'s sale serves to cover up a more fundamental ignorance about its real world effects. And since, on the other, this kind of knowledge usually comes along with globally hyped productions, it cannot be ignored. To "not even ignore them in the first place", ${ }^{72}$ as was Norbert Bolz' ironical (or cynical?) advice in the case of Jeff Koons, is not an option.

Therefore it is necessary to disenchant the emotional traps set by such 'compound-excited' artifacts and their 'better knowledge'. This is to be achieved by the patient and diligent analysis of the perversion endemic in both capitalist society and the single subject. On the societal level, such an analysis must - to sum up - denounce (1) the aesthetically decomposed yet libidinally compounded concurrence of pleasure and pain, respectively of love drive and death drive; (2) the preemptive complicity foisted on the beholder in the form of self-deceiving 'better knowledge' and (3) the dire effects Hirst \& Co.'s dumping triggers as it extorts real economic surplus-value, the diamond industry notoriously being linked to, among other evils, warlords, child soldiers, corrupted elites and the deterioration of the environment, to speak only of the African continent. Supplementing artifacts like Hirst's in this way by critical reflection, it should be possible to dissolve their fascination and to reduce their interest to the 'compound interest' which they arouse publicly or rather bear economically. As venture capital enterprises like Hirst \& Co. venture to dump and liquidate the very subject matter of art, it is the Romantic project of aesthetics to critically consummate its value.

\section{Notes}

1. Georg W.F. Hegel, Aesthetics: Lectures on Fine Art, vol. 2. Reprint. Translated by T. M. Knox (Oxford: Clarendon Press, 2010), 810.

2. Hegel, Aesthetics, vol. 2.

3. Theodor W. Adorno, Aesthetic Theory (London and New York: Continuum, 2004), 105 .

4. Grant Kester, "Aesthetics after the End of Art: An Interview with Susan Buck-Morss", Art Journal 56, no. 1 (Spring, 1997): 38-45. 
5. Cf. the various studies completed by the German Collaborative Research Centre 626 on "Aesthetic Experience and the Dissolution of Artistic Limits", accessed April 18, 2014, http://www.sfb626.de/en/index.html.

6. Arthur Danto, "The End of Art: A Philosophical Defense", History and Theory 37, no. 4 (Dec., 1998), 127-43, here 140.

7. Jean-François Lyotard, La condition postmoderne (Paris: Minuit, 1979), 31. Translation mine (W.B.).

8. Ibid. Translation mine (W.B.).

9. Georg W. F. Hegel, Phenomenology of Spirit. Translated by A.V. Miller. Edited by J.N. Findlay (Oxford: Oxford University Press, 1977), 111ff.

10.Cf. Gustav Th. Richter, Spinozas philosophische Terminologie (Leipzig: Barth, 1913), chapters 4 and 5 .

11. Johann G. Herder, Gott, in Werke in sechs Bänden, vol. 5, 6th edition (Leipzig: Aufbau, 1982).

12. Axel Honneth, "A Social Pathology of Reason: On the Intellectual Legacy of Critical Theory", in The Cambridge Companion to Critical Theory, ed. Fred Rush (Cambridge: Cambridge University Press, 2004), 336-6o, here 346.

13. Ibid.

\section{Hegel, Phenomenology, 117.}

15. Plasticity, both in the sense of formability and of resisting and outliving external impact, has rightly been highlighted by Catherine Malabou (Catherine Malabou, L'avenir de Hegel: Plasticité, temporalité, dialectique (Paris: Vrin, 1996), 162ff.) as a key concept to understand the theological import of Hegel's theory of subjectivity; however, Malabou, albeit writing in the tradition of Derrida, ignores the peculiar complexity of Hegel's sublation of three-dimensional plasticity which will be tackled in the following.

16. Hegel, Phenomenology, 117.

17. Hegel, Aesthetics, vol. 2, 810 .

18. Theodor W. Adorno and Hanns Eisler, Composing for the Films (New York: Oxford University Press, 2005), 70.

19. Ibid., 71.

20. See for example Robert Pippin, After the Beautiful (Chicago: University of Chicago Press, 2014) and, not differently, Benjamin Rutter, Hegel on the Modern Arts (Cambridge: Cambridge University Press, 2010). Pippin's anthology plainly ignores the role death (that is imagined death respectively the internalized death threat) and the mortification of the sensuous plays for the constitution of both (inter-)subjectivity and works of art. The consequence is Pippin's bewildering claim that nothing "essential" would motivate Hegel's - consequently inconsistent - step from the Classical to the Romantic artform: "[Hegel] [...] understands romantic art as the beginning of the realization that Geist does not require a material embodi- 
ment to be fully realized Geist; it needs only to be reconciled, with itself'. I shall suggest that this conclusion is not motivated by anything essential in Hegel's account and represents a misstep, not an inference consistent with Hegel's overall project." (Pippin 22f.) Here, Pippin's commentary is, sit venia verbo, dead wrong. In Hegel's art philosophy it is precisely the (presumably achieved) overcoming of death which essentially motivates the life of modern (Romantic) spirit, i.e. intersubjectivity.

21. Hegel, Aesthetics, vol. 2, 467n627.

22. Georg W.F. Hegel, Aesthetics: Lectures on Fine Art, vol. 1. Reprint. Translated by T. M. Knox (Oxford: Clarendon Press, 2010), 535.

23. Ibid.

24. Ibid.

25. Hegel, Aesthetics, vol. 2, 805 .

26. Ibid., $805 \mathrm{f}$.

27. Ibid., 804f.

28. Ibid., 806 .

29. Ibid.

30. Ibid., $804 \mathrm{ff}$.

31. Ibid., 806.

32. Jacques Derrida, "The Pit and the Pyramid: Introduction to Hegel's Semiology", in Derrida, Margins of Philosophy, trans. Alan Bass (Chicago: University of Chicago Press, 1982), 69-108 and Jacques Derrida, Glas, trans. John P. Leavey, Jr. and Richard Rand (Lincoln \& London: University of Nebraska Press, 1986).

33. Hegel, Aesthetics, vol. 1, 535 .

34. Hegel, Aesthetics, vol. 2, 811.

35. Ibid., 812.

36. Gerhard Richter, Panorama (Munich: Prestel, 2012), 150.

37. Hegel, Aesthetics, vol. 2, $837 \mathrm{ff}$.

38. Ibid., 848 .

39. Arnold Gehlen, Zeit-Bilder: Zur Soziologie und Ästhetik der modernen Malerei (Bonn: Athenäum, 1960), 65.

40. Ibid.

41.Cf. "Andreas Gursky", accessed on April 18, 2014, http://www.moma.org/ interactives/exhibitions/2001/gursky.

42. "For the Love of God": "Sale", "Media Reporting and Reviews", accessed on April 18, 2014, http://en.wikipedia.org/wiki/For_the_Love_of_God.

43. Photograph taken by and used with permission of Dr. Alexandra von Stosch at Art Basel 2013.

44. Hegel, Aesthetics, vol. 2, 846.

45. Ibid. 847 . 


\section{Wolfram Bergande}

46. Cf. Zygmunt Bauman, Culture in a Liquid Modern World (Cambridge: Polity Press, 2011).

47. In a lecture in 2011 Esther Leslie used the technical term liquid crystal display, referring to the so-called LCDs built into smartphones and flat screen television sets, as a metaphor for the aesthetics of contemporary capitalism. Cf. Esther Leslie, "Crowds, Clouds, Politics and Aesthetics, Flipping Again", The Nordic Journal of Aesthetics, no. 44-45 (2012-2013), 8-27.

48. Georg W. F. Hegel, Vorlesungen über die Philosophie der Religion II, in Werke, 17 (Frankfurt am Main: Suhrkamp, 1986), 123.

49. Karl Marx and Friedrich Engels, Manifesto of the Communist Party [1849], trans. Samuel Moore [1888], in Marx/Engels, Selected Works, vol. 1 (Moscow: Progress Publishers, 1969), 98-137.

50. Theodor W. Adorno, "The Meaning of Working Through the Past", in Adorno, Critical Models: Interventions and Catchwords, trans. and with a preface by Henry W. Pickford (New York: Columbia University Press, 1998), 339.

51. "For the Love of God", last accessed April 18, 2014, http://en.wikipedia.org/ wiki/For_the_Love_of_God.

52. Theodor W. Adorno, "Culture Industry Reconsidered", New German Critique, no. 6 (Fall 1975), trans. Anson G. Rabinbach, 7.

53. Wolfgang Ullrich, An die Kunst glauben (Berlin: Wagenbach, 2011), 102.

54. Ibid., 103 .

55. Luke White, "Damien Hirst's Diamond Skull and the Capitalist Sublime", in The Sublime Now, ed. Luke White and Claire Pajaczkowska (Newcastle upon Tyne: Cambridge Scholars Publ., 2009), 155-73, here 155 f.

56. Fredric Jameson, Postmodernism or the Cultural Logic of Late Capitalism (Durham: Duke University Press, 1991), 37.

57. Ibid.

58. Ibid., 36 .

59. White, "Damien Hirst's Diamond Skull", 159.

6o. Ibid., 166.

61. Ibid.

62. Ibid., 167 .

63. Ibid., 166

64. Ibid.

65. Ibid., 167

66. Ibid., 155 .

67. Ibid., 167.

68. The position of alleged better knowledge and the economy of mixed pleasures behind it has been described (yet also been uncritically affirmed) by Robert Pfaller, Die Illusionen der anderen (Frankfurt am Main: Suhrkamp, 2002). Pfaller 
bases his argument on Octave Mannoni: “Je sais bien, mais quand meme...", in Mannoni, Clefs pour l'imaginaire ou l'Autre scène (Paris: Seuil, 1969), 9-33. For a critical review of Pfaller's text see Wolfram Bergande, "Das Blinzeln der letzten Menschen. Ein Rezensionsessay zu R. Pfallers Die Illusionen der anderen", RISS 75 (2010), 100-14; http://www.bergande.de/wp-content/uploads/2009/o1/ Bergande_Das-Blinzeln-der-letzten-Menschen_Rezensionsessay-zu-Pfaller_DieIllusionen-der-anderen_RISS-75-2010_S-100-114.pdf.

69. Terry Eagleton, The Ideology of the Aesthetic (Oxford: Basil Backwell, 1990), 377.

70. Immanuel Kant, Kant's Critique of Judgement, ed. and trans. J. H. Bernard (London: Macmillan, 1914), $\mathbb{2} 27,123$.

71. Jacques Lacan, Le Séminaire live XVII: L'envers de la psychanalyse (Paris: Seuil, 1991), 52. Translation mine (W.B.).

72. Norbert Bolz, "Marketing als Kunst oder: Was man von Jeff Koons lernen kann", in Riskante Bilder, ed. Norbert Bolz et al. (Munich: Fink, 1996), 129-36, here 136. Translation mine (W.B.). 